IZA DP No. 8153

Welfare Reform and Immigrant Fertility

Catalina Amuedo-Dorantes

Susan L. Averett

Cynthia A. Bansak

April 2014 


\title{
Welfare Reform and Immigrant Fertility
}

\author{
Catalina Amuedo-Dorantes \\ San Diego State University \\ and IZA \\ Susan L. Averett \\ Lafayette College \\ and IZA
}

Cynthia A. Bansak

St. Lawrence University

Discussion Paper No. 8153
April 2014

IZA

P.O. Box 7240

53072 Bonn

Germany

Phone: +49-228-3894-0

Fax: +49-228-3894-180

E-mail: iza@iza.org

Any opinions expressed here are those of the author(s) and not those of IZA. Research published in this series may include views on policy, but the institute itself takes no institutional policy positions. The IZA research network is committed to the IZA Guiding Principles of Research Integrity.

The Institute for the Study of Labor (IZA) in Bonn is a local and virtual international research center and a place of communication between science, politics and business. IZA is an independent nonprofit organization supported by Deutsche Post Foundation. The center is associated with the University of Bonn and offers a stimulating research environment through its international network, workshops and conferences, data service, project support, research visits and doctoral program. IZA engages in (i) original and internationally competitive research in all fields of labor economics, (ii) development of policy concepts, and (iii) dissemination of research results and concepts to the interested public.

IZA Discussion Papers often represent preliminary work and are circulated to encourage discussion. Citation of such a paper should account for its provisional character. A revised version may be available directly from the author. 


\section{ABSTRACT \\ Welfare Reform and Immigrant Fertility ${ }^{1}$}

Immigration policy continues to be at the forefront of policy discussions, and the use of welfare benefits by immigrants has been hotly debated. In 1996, Congress enacted welfare reform legislation (PRWORA), which denied the use of most means-tested assistance to noncitizens and lowered immigrant welfare dramatically. While Federal legislation imposed strict restrictions on eligibility for non-citizens, a number of states allowed previously eligible women to continue to receive benefits similar to those before 1996, whereas others imposed the new Federal cutbacks. Using data from the Current Population Survey (CPS) for the years 1994-2000, we examine whether immigrant women adjusted their childbearing in response to cutbacks in the generosity of welfare benefits at the state-level. Our findings suggest that non-citizen women, especially those of Hispanic origin, altered their fertility decisions in response to the legislation. In addition, they increased their labor force participation, possibly to obtain employer-sponsored benefits. Our results are robust to alternative definitions of our treatment and control groups and do not appear to be driven by pre-existing trends. Finally, we find no evidence that women who anticipated having children migrated to the more generous states. Overall, the results provide further evidence that immigrants respond to variation in state-level policies and provide insight into the potential impacts of comprehensive immigration reform, particularly the components related to the path to citizenship and access to public benefits.

JEL Classification: J13, I38

Keywords: immigration, fertility, welfare reform

Corresponding author:

Susan Averett

Department of Economics

Lafayette College

Easton, PA 18042

USA

E-mail: averetts@lafayette.edu

${ }^{1}$ The authors thank Laura Argys and seminar participants at the Eastern Economics Association Meetings (EEA), Colgate University, IZA Bonn and Colorado State University for helpful comments on earlier drafts. 


\section{Introduction}

Immigrants in the United States are a diverse and growing population. Issues surrounding immigration have long been at the forefront of policy discussions. A long-standing policy discussion has centered on the costs imposed by immigrants and their children. It has been argued that immigrant children inflict substantial expenses on local and state-level governments in charge of education and health-related expenditures (Borjas, 1999). And, although such allegations have been questioned by various researchers (see Griswold (2012) for a review of that literature), they have implanted a genuine concern in society about the ability of immigrants "to pay their way" into the welfare state and the possibility that welfare serves as a magnet. These concerns were probably partially responsible for some of the provisions in the 1996 Personal Responsibility and Work Reconciliation Act (PRWORA). In the legislation, PRWORA denied most means-tested assistance to immigrants arriving after its enactment date of August 22, 1996, during their first 5 years of legal residency in the United States. Additionally, it limited the eligibility of non-citizens arriving before that date to one year - although this latter provision was never fully enforced. Not surprisingly, immigrant welfare participation decreased (Borjas, 2001; Mazzolari, 2004; Bitler and Hoynes, 2011). However, we still do not know how immigrant fertility was impacted by PRWORA.

In this paper, we use data on the fertility of the non-institutionalized population collected by the Current Population Survey (CPS) in June for the years 1994, 1995, 1998 and 2000 to address that gap in the literature by examining how PRWORA affected the fertility of immigrant women. ${ }^{2}$ Because PRWORA reduced immigrant eligibility and welfare participation, it seems reasonable to expect welfare reform to have significantly lowered immigrant fertility. And,

\footnotetext{
${ }^{2}$ Similar to Borjas (2003) we do not use the years 1996 and 1997 in our analysis. This allows us to isolate the preand post-PRWORA time periods.
} 
indeed, we find that non-citizens living in states that did not offer state-funded benefits such as Medicaid or TANF reduced their fertility in response to the legislation. Furthermore, these women became more likely to be at work, possibly to replace lost benefits with employersponsored benefits.

Understanding how immigrant fertility responds to policy changes is particularly important given that immigrant women tend to have more children than their native counterparts (Dye, 2008). Looming concerns about the solvency of the Social Security system and an aging population that could benefit from a younger workforce make understanding determinants of immigrant fertility a particularly salient concern (d'Addio and d'Ercole, 2005; Sevak and Schmidt, 2008).

\section{Background on Welfare Reform and Immigrant Fertility}

Previous literature has established links between fertility and welfare benefits. For example, researchers examined how the Aid to Families with Dependent Children (AFDC) program -the precursor to the current welfare system: Temporary Assistance to Needy Families (TANF)- impacted the fertility of AFDC eligible women (primarily low educated and unmarried). For the most part, these studies exploited the state-level variation in AFDC benefits across time and, as summarized by Moffitt $(1992,1998)$, their main conclusion was that the effects of AFDC benefits on fertility were small to non-existent.

In the time period leading up to PRWORA, states were granted waivers to experiment with policies aimed at reducing the fertility of recipients. For example, a number of states enacted the "minor parent provision" - requiring that a teen who received welfare must live at home with her parents (or under adult supervision) to receive benefits. Many states also enacted 
"family caps" - provisions that denied incremental increases in welfare benefits for women who had another child while receiving benefits.

After the passage of PRWORA, more states adopted such policies and these policies, in addition to the work requirements and time limits on welfare receipt contained within PRWORA, made it more difficult to support a child while on welfare, thus raising the cost of a birth. Much research has been aimed at discovering how these PRWORA provisions may have affected the fertility of welfare eligible women. The evidence from these other studies has been, however, quite mixed (see Blank, 2002 for a review of these studies). Notably, although Hispanic women - many of whom were immigrants, had the highest rates of teenaged and non-marital childbearing of any major racial or ethnic group in the United States before welfare reform (Graefe et al., 2008), ${ }^{3}$ none of the studies examined how immigrant fertility was impacted by PRWORA and the state provisions. In fact, we only know of one study examining the fertility of Hispanic immigrants (i.e. Falasco and Heer, 1984). However, the analysis predates welfare reform and, as such, does not address how welfare reform impacted immigrant fertility.

We are particularly interested in addressing that question - namely, how the fertility of immigrant woman changed after the imposition of PRWORA. With the enactment of PRWORA, Congress imposed a variety of restrictions on legal immigrants' access to welfare, which may have also had an effect on their fertility above and beyond changes in work requirements, family caps and time limits on the receipt of benefits. PRWORA dramatically altered the access of non-citizens to programs such as TANF, food stamps and Medicaid. In particular, after PRWORA, non-citizens, particularly those arriving post-enactment, became ineligible for TANF and Medicaid for their first five years living in the United States, although

\footnotetext{
${ }^{3}$ Moffitt (2003) provides an excellent overview of the TANF program.
} 
states could offer benefits to new immigrants using their own funds (Haskins, 2006; Nam, 2011; Bitler and Hoynes, 2011). Legal temporary residents and undocumented immigrants were never eligible for federal welfare benefits and, hence, should have experienced few, if any, changes after welfare reform (Fix and Zimmerman, 1998). The greatest variation in access to welfare among immigrants has been for post-enactment arrivals, i.e. those immigrants who arrived after PRWORA as a result of the federal requirement that any funding of benefits for that group must not be paid for with federal monies (Fix and Passel, 2002). Yet, although TANF is the most expensive benefit for states to provide, many states continued to support recent immigrant families using their own state funds (Graefe et al., 2008; Bitler and Hoynes, 2011). ${ }^{4}$

Because states had the option to extend welfare benefits to immigrants who arrived after August 22, 1996, and virtually all states extended benefits to pre-enactment immigrants (Fix and Zimmermann, 1998), there was some uncertainty over who was eligible for benefits. This confusion led to what Fix and Passel (1999) termed a 'chilling effect', which may have discouraged immigrants from using benefits such as TANF and Medicaid even though they remained eligible. Evidence on the existence of this chilling effect can be found in the literature linking PRWORA to health insurance. For example, Lurie (2008) examines the effect of welfare reform on the health insurance coverage of children of non-permanent residents. Specifically, using data from the Survey of Income and Program Participation (SIPP), Lurie finds that the proportion of uninsured citizen children of non-permanent residents rose by 17 percentage-points post-PRWORA despite the fact that these children were eligible for Medicaid. In a similar vein,

\footnotetext{
${ }^{4}$ Immigrant participation in welfare programs kept on growing since then (Borjas, 2003). Hence, one might ask: why did some states decide to maintain immigrants' access to programs such as TANF, food stamps and Medicaid while other states did not? Early work on this question indicated that the size of the state's noncitizen population was unrelated to program generosity toward immigrants in the first years following PRWORA (Zimmerman and Tumlin, 1999). However, states with strong immigrant advocacy groups and a liberal voting public were more consistent predictors of state generosity towards immigrants (Graefe et al. 2008).
} 
Kalil and Ziol-Guest (2009) use SIPP data to examine, instead, the effect of PRWORA on the health of the children of immigrants. Most of the children in their sample were born in the United States and would have, thus, remained eligible for Medicaid even after welfare reform. Yet, the health of these children was poorer after the passage of PRWORA. The authors interpret this finding as a chilling effect of welfare reform on immigrant children's access to health services. In further support of this chilling effect, an evaluation of welfare reform's effect on immigrants conducted in Los Angeles and New York City found that many immigrants believed that receiving welfare benefits might endanger their immigration status or prevent them from obtaining green cards, reentering the country, or becoming citizens. Further, many immigrant families indicated that they were confused by the changes in welfare rules that occurred in 1996. Therefore, many immigrants might have believed that all foreign-born were disqualified (Capps et al., 2002).

Particularly relevant to our analysis are several recent papers focused on the effect of PRWORA provisions on the health insurance coverage of immigrants (Borjas, 2003; Kaushal and Kaestner, 2005) -a crucial factor in deciding whether to have children. Using data from the 1995 to 2001 Current Population Surveys (CPS) and a difference-in-difference methodology, Borjas (2003) compares changes in the health insurance coverage of immigrants in more generous states following the enactment of PRWORA, to the health insurance coverage changes experienced by immigrants in less generous states. He finds that the fraction of immigrants not covered by health insurance remained more or less stable (or slightly fell) after PRWORA. Since most non-citizens in the sample had arrived before 1996 and, therefore, maintained eligibility for Medicaid, Borjas concluded that the small declines in Medicaid participation stemmed from the chilling effects of welfare reform. Overall, however, the fact that health 
insurance coverage among the immigrant population did not change much is attributed to their increased labor supply, which likely increased their probability of being covered by employersponsored health insurance. Therefore, he does find a labor market adjustment as a result of state-level generosity in welfare and Medicaid benefits.

Kaushal and Kaestner (2005) use data from the CPS (years 1994 to 2001) and a similar difference-in-differences research design to extend Borjas' (2003) analysis. They focus on loweducated unmarried women (a group they term: "target group") and, instead of native women, they use other immigrants as a control group. In addition, they carefully examine the 'chilling effect' hypothesis. They do so by, first, dividing the group of low-educated unmarried immigrants into two sub-groups: those who arrived less than five years ago and those that arrived more than five years ago. They argue that, if the two groups were similarly affected by PRWORA, it would be consistent with the chilling effect hypothesis because immigrants who arrived more recently should be more adversely affected by the law. Subsequently, they differentiate pre-1996 arrival and post-1996 arrival immigrants according to whether they lived in a state that created a substitute TANF or Medicaid program for post-1996 immigrants. If PRWORA affected both groups of immigrants similarly, they argue that PRWORA must have had a chilling effect as well. They report that the effect of TANF on the health insurance coverage of foreign-born, unmarried women did not differ by their length of stay in the U.S. providing support for the chilling hypothesis.

Additional evidence of a chilling effect comes from Mazzolari (2004), who examines the differential drop in welfare use among immigrants relative to natives after the 1996 Welfare Reform Act. She limits her sample to naturalized citizens and immigrants who arrived before 1996 —-these immigrants were still treated as similarly under the new law. She reports a 
significant drop in the welfare participation of non-citizen immigrants (relative to natives) that is not explained by mere changes in program eligibility. She interprets that effect as evidence of a chilling effect. Basically, even women who were eligible for benefits choose not to collect them. Finally, in closely related work, Watson (2010) focuses on the increase in federal immigration enforcement that occurred around the time of welfare reform. She reports that increased federal immigration enforcement reduces Medicaid participation among children of non-citizens, even when children are themselves citizens.

Despite this evidence on chilling effects of PRWORA on immigrant health insurance coverage, to this date, we still lack any empirical evidence on the existence of chilling effects or, for that matter, of any overall effect of PRWORA on immigrant fertility. Yet, understanding how welfare policy shapes immigrant fertility is of special interest given growing concerns about the solvency of the U.S. Social Security system.

\section{Data and Some Descriptive Statistics}

To examine how the enactment of PRWORA affected the fertility of immigrant women, we gather data on the fertility of the non-institutionalized female population collected by the Current Population Survey (CPS) in June for the years 1994, 1995, 1998 and 2000. The survey also gathers information on the immigration status of respondents, allowing us to differentiate between native born U.S. citizens, those who are foreign-born naturalized U.S. citizens and foreign-born who have not become citizens. Additionally, with the information on their year of arrival to the United States, we are able to differentiate foreign-born non-citizens according to 
whether they had been in the country at least 6 years -making them eligible for most types of public assistance, or less. ${ }^{5}$

Because our focus is on fertility, we limit our analysis to women aged 15 to 44 . Additionally, we restrict our attention to women most likely to qualify for welfare; i.e. unmarried women with a high-school education or less (similar to Kaushal and Kaestner, 2005). Table 1 displays basic descriptive statistics regarding the share giving birth for our various sub-samples. Overall, there are significant differences in fertility across respondents depending on their immigration status and ethnicity. As can be seen from Table 1, the share of women in our sample giving birth in the survey year is significantly higher among immigrants, particularly among non-citizens. This is also the case for Hispanics, regardless of their immigration status. The fertility rates in Table 1 range from 8.88 percent for non-Hispanic natives, to 15.61 percent for Hispanic foreign-born non-citizens. Meanwhile, the share of native women giving birth averaged 9.03 percent in our sample.

As noted, PRWORA eliminated benefits to immigrants for their first five years of arrival in the United States. However, a key provision of PRWORA was that a state could choose to fund these benefits for immigrants and many states choose to do this. We follow Borjas (2003) and classify states as being generous (i.e. they replaced federal cuts with state monies to maintain at least some benefits for immigrants) and non-generous (i.e. they did not replace federal cutbacks with state aid). These states are presented in Table A in the appendix. There are two columns in this table: the first one indicates whether or not food assistance or SSI was provided

\footnotetext{
${ }^{5}$ There are several ways that immigrants can be categorized: naturalized citizens (foreign-born individuals who became citizens); legal permanent residents (noncitizens who have been granted permission to reside permanently in the United States and to apply for naturalization after meeting certain requirements); and refugees and asylees (individuals admitted to the United States who are unable or unwilling to return to their home countries due to legitimate fear of persecution. In addition, the foreign-born population includes legal temporary residents (e.g., students or those with temporary work visas) and undocumented immigrants (individuals who stay in the United States illegally; i.e. beyond their visa limits or those who enter the country illegally and stay).
} 
to post-enactment immigrants, whereas the second column indicates whether or not TANF, Medicaid, Food Assistance or SSI was provided to post-enactment immigrants during the 5-year post immigration period. We classify as generous any state with a 'Yes' in either column. The generous states include California, Colorado, Connecticut, Delaware, Florida, Georgia, Hawaii, Illinois, Maine, Maryland, Massachusetts, Minnesota, Missouri, Nebraska, New Hampshire, New Jersey, New York, Ohio, Oregon, Pennsylvania, Rhode Island, Tennessee, Texas, Utah, Vermont, Virginia, Washington, Wisconsin and Wyoming.

We distinguish between five groups of women in our regression analyses. Summary statistics for these five sub-samples are shown in Table B in the appendix. First, we start by comparing Hispanic immigrants -who constitute a large share of all immigrants in the United States and have significantly higher fertility rates, to non-Hispanic natives -also the vast majority of U.S. natives (sample in Panel A). We then expand the native sample to include Hispanic natives, and compare their fertility to that of Hispanic immigrants (sample in Panel B). Subsequently, we restrict our attention again to non-Hispanic natives and compare them to all immigrants, regardless of their ethnicity (sample in Panel C). We then look at all natives and all immigrants (sample in Panel D), which constitutes our largest sample of 34,238 individuals. Finally, we compare Hispanic immigrants to Hispanic natives (sample in Panel E).

According to the figures in Table B, about 26 percent of women in the largest sample (sample in Panel D) resided in states that did not go beyond-the-minimum level of assistance offered to pre-enactment or post-enactment immigrants during the 5-year bar, and roughly 51 percent of our sample was interviewed after the enactment of PRWORA. Approximately 9 percent of women in our pooled sample are immigrants -8 percent of those are non-citizens, while the remaining 1 percent is naturalized. Most immigrants arrived between 1980 and 1993; 
therefore, they were not subject to the 5-year bar. Finally, other sample characteristics worth noting include race and ethnicity. Up to 25 percent of our sample is black and 15 percent Hispanic. This is due to our focus on women more likely to qualify for welfare (i.e. unmarried and low-educated women). On average, these women have slightly less than one child -the exception being Hispanic women (Panel E), who have slightly more than one child. Similarly, slightly more than half of our relatively low-educated sample has less than a high-school education, except for Hispanic women, who are significantly less educated.

In Table 2, we conduct a descriptive double-difference analysis using average birth rates for various groups before and after the passage of PRWORA in states that had cutbacks in welfare eligibility and in states that did not. To conduct this analysis, we divide our sample into five panels (Hispanic immigrants, all immigrants, non-Hispanic natives, all natives, and Hispanic natives); two groups of states (states with cutbacks and states without welfare eligibility cutbacks) and two time periods (pre-PRWORA and post-PRWORA).

As seen in Panel A of Table 2, while the share of Hispanic immigrants giving birth while residing in more generous states increased from 6.3 to 13.0 percent (an increase of 6.6 percentage points) following the enactment of PRWORA, it declined for their counterparts living in less generous states by 3.8 percentage points. As a result, the double-difference estimate in column 7 of Table 2 indicates that the share of Hispanic immigrants giving birth while living in less generous states significantly dropped by 10.3 percentage points after welfare reform. That is, in fact, the demographic group we would expect to respond to the welfare eligibility restrictions imposed by PRWORA. For all immigrants (Panel B of Table 2), the likelihood of giving birth decreased by 1.1 percentage points when living in less generous states, whereas it increased by 5.2 percentage points for those living in the more generous states; thus leading to a 
statistically significant reduction of 6.3 percentage points in the probability of childbearing. While the double-difference estimates for non-Hispanic natives, all natives and Hispanic natives (Panels C, D and E of Table 2) are also negative, they are not economically large.

Because the aforementioned difference-in-difference estimates focus on immigrants, it is useful to compare what the apparent impact of PRWORA was for those groups to how fertility patterns were changing among natives. We do so in the last three columns of Table 2. Regardless of whether we use non-Hispanic native women or all native women as a comparison group, the triple difference estimates suggests that PRWORA lowered Hispanic immigrant women's childbearing likelihood by approximately 9.4 percentage points. When we widen the treatment group to all immigrant women, we continue to find a statistically significant reduction in the likelihood of giving birth, but the point estimate is much smaller at 5.4 percentage points. Finally, when we restrict our groups to Hispanics and compare immigrants to natives, we find a statistically significant decline in the fertility of Hispanic immigrants relative to Hispanic natives. This latter finding speaks against a chilling effect. In other words, we would expect a significant difference in these two groups' childbearing propensities after the policy, which is exactly what we find. In the next section, we extend our methodology to add additional controls and address heterogeneity in our immigrant group.

\section{Methodology}

Our primary aim is to gauge the impact that the 1996 welfare reform might have had on the fertility of foreign-born women and, in particular, of foreign-born non-citizens. With that intent, we classify foreign-born women in two groups: foreign-born naturalized and foreign-born non-citizens. We pursue a triple difference specification where we pool the CPS data for the 
calendar years 1994, 1995, 1998 and 2000 and estimate linear probability models where the dependent variable is equal to 1 if the ith woman had a birth in that year:

$$
\begin{aligned}
& y_{i s t}=\alpha+X_{i s t} \beta+\gamma_{1} \text { Post }_{t}+\gamma_{2} I_{i}+\gamma_{3} C_{s}+\gamma_{4}\left(\text { Post }_{t} * I_{i}\right)+\gamma_{5}\left(\text { Post }_{t} * C_{s}\right)+ \\
& \gamma_{6}\left(I_{i} * C_{s}\right)+\gamma_{7}\left(\text { Post }_{t} * I_{i} * C_{s}\right)+\gamma_{8} U R_{s t}+\delta_{s}+\theta_{t}+\delta_{s} t+\varepsilon_{i s t}
\end{aligned}
$$

where $y_{i s t}$ is a dummy variable that equals 1 if the $i$ th woman living in state $s$ had a birth in year $t$. The vector $X_{\text {ist }}$ contains various socioeconomic characteristics of the woman including her age, race, ethnicity (when working with all natives and immigrants), and educational status. Post $t_{t}$ is a dummy equal to 1 if the observation refers to the post-PRWORA period (that is: 1998-2000). The vector $I_{i}$ indicates the immigration status of the respondent. In our simplest specification, $I_{i}$ equals 1 if the person is foreign-born. In subsequent specifications, $I_{i}$ stands for a set of dummy variables indicative of whether the respondent is a naturalized immigrant or a foreign-born noncitizen. ${ }^{6}$ The reference group is native-born women who are similarly skilled and are also unmarried. The variable $C_{s}$ represents the generosity of the state and it equals 1 when the respondent lives in a state that cutback welfare generosity after PRWORA (i.e. did not use their own funds to replace lost funds for immigrants). Specifically, $C_{s}$ is set to unity if the state did not offer any of the programs listed in the first two columns of the Appendix table A. Finally, equation (1) also includes the state's unemployment rate at time $t\left(U R_{s t}\right)$, as well as a set of state fixed-effects $\left(\delta_{s}\right)$, year fixed-effects $\left(\theta_{t}\right)$ and state-time trends $\left(\delta_{s} t\right)$. Standard errors are clustered at the state level.

\section{Results}

\footnotetext{
${ }^{6}$ Because immigrants who have been in the country for five years or longer could apply for benefits, splitting the sample according to the migration spell of migrants would make sense given that the cutbacks exclusively impacted newly arrived immigrants. Note, however, that our last year of data is 2000 and PRWORA was enacted in 1996. Therefore, all naturalized immigrants (all with, at least, 5 years of permanent residency in the United States) in our sample had arrived pre-PRWORA. Similarly, all immigrants who arrived post-PRWORA in our sample are noncitizens.
} 


\section{A) Immigrant Fertility Response}

Table 3 displays the triple-difference coefficient vector $\gamma_{7}$ estimated using the various samples previously discussed and included in Panels A through E of Table B in the appendix. The specification reported in the first column does not include any controls and is identical to the specification in the last three columns of Table 2. Specification (2) includes some basic controls, such as age, race and ethnicity, when applicable. Specification (3) further adds educational attainment, the number of children and a set of year of arrival dummies. Finally, specification (4) includes all the controls in specification (3) plus the state unemployment rate, state fixedeffects, year fixed-effects and state-time trends. Specifically, the state-specific time trends allow us to account for differences in fertility trends rates across states driven by factors other than welfare reform, such as changes in the political and economic dynamics of the states not captured by the unemployment rate or the welfare non-generosity (i.e. $C_{s}$ ) measure.

Across all five panels and all four specifications, the coefficients on the triple interaction term are negative, and for the first three Panels (A, B and C) the coefficient is statistically significant even when adding the full set of controls. In Panel A, fertility rates drop between 6.8 and 9.4 percentage points for Hispanic immigrants relative to non-Hispanic natives. Similar declines are found when expanding the control group to all natives, as shown in Panel B. In Panel C, we widen the treatment group to include all immigrant women and compare them to non-Hispanic natives. We find that the point estimate is negative, but smaller (4.3 in the full specification). Finally, in Panels D and E, as we compare all natives to all immigrants or Hispanic natives to Hispanic immigrants, the point estimates become insignificant in the most complete specification. These more muted results in Panels C, D and E may be picking up chilling effects felt by Hispanic Native-born women who are acting as controls in these 
specifications. Panel E is a direct test of this hypothesis. While in Table 2 there was a statistically significant difference between Hispanic immigrants and natives which suggests no chilling effect, in Table 3 we find no difference which points towards a chilling effect. Overall, the results in Table 3 suggest that Hispanic immigrants, in particular, are driving the statistical significance of the policy on the fertility rates of immigrants.

Table 4 further delineates the sample and provides two triple-difference coefficients that allow for differential effects among naturalized and foreign-born non-citizens. Specifications (1) to (4) are similar to those presented in Table 3. And, just as we found in Table 3, the triple difference estimates for naturalized immigrants in Table 4 are negative, but not statistically different from zero at conventional levels of significance. Not finding a significant reduction in fertility for that group is not surprising, and it simply suggests that this group was likely aware of the fact that these changes did not pertain to them. ${ }^{7}$ In contrast, the impact of welfare reform on the fertility of foreign-born non-citizen women closely tracks the effects found in Table 3. Notably, in less generous states, foreign-born non-citizen women, particularly Hispanics, lowered the childbearing propensities by up to 10.6 percentage-points. Although birthright citizenship was not altered by the legislation and the children of immigrants would continue to have U.S. citizenship if born in the United States, our results suggest that a scaling back of public services dissuaded Hispanic immigrant women in less generous states from having children.

\section{B) Immigrant Employment Response}

In order to understand the driving forces behind the fertility decisions made by immigrant women, we also explore how state-level variation in generosity influenced these women's labor

\footnotetext{
${ }^{7}$ Note that the standard errors for this group are quite a bit larger, but the point estimates also fall by around half, making this group less responsive than the foreign-born not citizen group. Nonetheless, any response to the policy by this group is indicative of a chilling effect.
} 
supply. Of special interest to us is whether welfare reform induced these women to search for employment -possibly as a means to obtain health insurance coverage, and increased employment, in turn, lowered their childbearing likelihood. If, indeed, that was the case, foreign-born non-citizen women in less generous states should seem more likely to be at work after PRWORA than their native counterparts.

The results in Tables 5 and 6 provide strong evidence that state-funded assistance programs did have a significant impact on the labor supply decisions of immigrants. In both tables, we present regression results for specifications and samples along the lines to those displayed in Tables 3 and 4. However, our dependent variable is now the probability of being employed. These regressions are also estimated as linear probability models for ease of exposition.

In Table 5, the coefficient on the triple difference in the models estimating the probability of being employed ranges from 8.8 to 15.8 for our five samples and our four specifications. There is some attenuation of the estimated impacts as additional controls are added to the model specification. As in the case in the fertility models, the largest and most robust estimates are found for Hispanic immigrants. This finding is consistent with prior findings in the literature according to which welfare reform increased the labor force participation of foreign-born, single mothers (Kaestner and Kaushal, 2006, Borjas 2003) .

In Table 6, we allow for differences by citizenship status of immigrants and compute two triple difference estimates for naturalized immigrants and foreign-born non-citizens. This table mirrors Table 4. The estimated coefficients consistently show that the employment probabilities of foreign-born non-citizen women increased sizably in those states that were less generous after PRWORA. The triple difference coefficients vary from 0.085 to 0.197 and are all statistically 
significant. Meanwhile, the triple-difference estimates for naturalized immigrants are never statistically significant in any of the 20 specifications.

In sum, our results provide evidence that the group most likely to be affected by the legislation -namely foreign-born non-citizens, particularly those of Hispanic origin- lowered their fertility and increased their labor supply in the aftermath of cutbacks in welfare eligibility.

\section{C) Robustness Checks}

One potential weakness of difference-in-difference analyses is the presence of pre-trends in the outcomes of interest prior to treatment. Specifically, in our case, we would be concerned if immigrant women already displayed lower fertility rates than their native counterparts prior to PRWORA. In that instance, we would not be able to conclusively assign the observed fertility impacts to the policy itself. To gauge if, indeed, fertility among immigrant women was already lower than that of native women prior to PRWORA, we conduct a falsification test. We restrict our sample to the years 1994 and 1995, and we falsely designate the post-PRWORA period to be 1995. The results from such an exercise for the various specifications being estimated in Tables 3 and 4 are displayed in Tables 7 and 8, accordingly. It is clear from the figures in those tables that immigrant women, in particular Hispanic non-citizens, were not less likely than their native counterparts to have children prior to PRWORA. In fact, if anything, they were more likely, signaling that the policy must have been particularly effective. In sum, pre-treatment trends are not driving our results.

Another logical concern that arises in this type of analysis refers to the endogeneity of immigrants’ location. The inverse relationship found between states’ lower welfare generosity and immigrant childbearing might not stem from the ongoing policy changes but, rather, from the fact that immigrant women planning on having a baby leave less generous states for more 
generous ones. To examine if, indeed, that was occurring, we compute the share of immigrants per state and year and estimate state-level regressions examining the extent to which those shares are correlated to changes in the states' generosity following the enactment of PRWORA. Results from this additional robustness check are displayed in Table 9. We find no evidence that states that became generous after the passage of welfare reform attracted more immigrants. ${ }^{8}$

\section{Summary and Conclusions}

We examine how the 1996 passage of PRWORA impacted the fertility of foreign-born women and, in particular, foreign-born non-citizen women. We find that non-citizen women living in states that did not offer state-funded food assistance or SSI following the enactment of PRWORA altered their fertility patterns in response to the new legislation. In contrast to earlier work that found evidence of a chilling effect on immigrants' use of benefits, we find results that are largely concentrated among the group targeted by the policy -namely: foreign-born noncitizens as opposed to naturalized immigrants. Our findings suggest that they may have entered the work force in order to receive benefits through their employer, as well as a sustainable level of income. These results line up with the evidence presented in Borjas (2003) regarding the switch to employer-provided health care from Medicaid among immigrant women as they became more likely to be employed. Overall, the findings provide further evidence of how immigrants respond to federal and state-level policy, contributing to the ongoing debate regarding state-level versus federal and comprehensive immigration policy.

\footnotetext{
${ }^{8}$ We deem the specification in Table 9 as the most appropriate, as it accounts for the state's population size. Nevertheless, we continue to obtain the same results when we use, instead, other measures of immigrant placement, including the absolute number of immigrants in the state or the share of immigrants in the state relative to the total in the country. These results are available from the authors.
} 
Understanding how welfare policy shapes immigrant fertility is of special interest given growing concerns about the solvency of the U.S. Social Security system. The rapidly aging population, coupled with fertility rates that are just at or below replacement level, have led analysts to view immigration as a way to alleviate pressure on the pay as you go social security system (Social Security Advisory Report, 2005). Immigrants have higher fertility than the native born population (Camarota, 2005; Sevak and Schmidt, 2008), in part due to their younger age. In 2002, immigrant women from the top 10 origin countries had a total fertility rate of 2.9-well above the 2.01 that existed for the entire United States at that time, and a greater rate than did women from their home countries (at 2.3). Among newly migrated Mexican women, the total fertility rate was even greater at 3.5 (Camarota, 2005). Our finding indicates that PROWRA decreased the fertility of immigrants; thus, policymakers need to be aware that this reduced fertility may have unintended consequences on the fiscal sustainability of other government programs. These results also provide insight into the potential impacts of comprehensive immigration reform, particularly the components related to the path to citizenship and access to public benefits. 


\section{References}

Bitler, Marianne P., Jonah B. Gelbach, and Hilary W. Hoynes. 2005. "Welfare Reform and Health.” Journal of Human Resources 40(2): 309-334.

Bitler, Marianne P. and Hilary W. Hoynes. 2011. "Immigrants, Welfare Reform and the U.S. Safety Net.” NBER Working Paper 17667.

Blank, Rebecca. 2002. “Evaluating Welfare Reform in the U.S.” NBER Working paper \# 8982.

Borjas, G. 2003. "Welfare Reform, Labor Supply and Health Insurance in the Immigrant Population.'” Journal of Health Economics 22: 933-58.

Borjas, G. 2001. “Welfare Reform and Immigration” in Blank, R., Haskings, R. (Eds.) The New World of Welfare: An Agenda for Reauthorization and Beyond. Brookings Press, Washington, DC, pp. 369-385.

Borjas, G. 1999. “Immigration and Welfare Magnets.” Journal of Labor Economics 17(4): 607637.

Camarota, S. A. 2005. "Birth rates among immigrants in America comparing fertility in the US and home countries.” Washington, DC: Center for Immigration Studies.

Capps, R., Leighton, K., Fix, M., Furgiuele, C., Passel, J., Ramchand, R., McNiven, S., PerezLopez, D., Fielder, E., Greenwell, M., Hays, T. 2002."How Are Immigrants Faring After Welfare Reform? Preliminary Evidence from Los Angeles and New York City": Report to the Office of the Assistant Secretary for Planning and Evaluation, Department of Health and Human Services. Washington, DC: Urban Institute, March 2002.

Carrasquillo, O., Ferry, D. H., Edwards, J., \& Glied, S. 2003. Eligibility for government insurance if immigrant provisions of welfare reform are repealed. American Journal of Public Health 93(10): 1680.

Cawley, J., Schroeder, M., \& Simon, K. I. 2006. "How did welfare reform affect the health insurance coverage of women and children?” Health Services Research 41(2), 486-506.

Cho, Rosa M. 2011. “Effects of welfare reform policies on Mexican immigrants' infant mortality rates.” Social Science Research 40(2): 641-653.

d’Addio, Anna Cristina and Marco Mira d'Ercole. 2005. “Trends and Determinants of Fertility Rates in OECD Countries: The Role of Policies” OECD Social, Employment and Migration Working Papers No. 27. Available online at: http://www.oecd.org/els/familiesandchildren/35304751.pdf.

DeLeire, Thomas, Judith Levine, and Helen Levy. 2006. “Is Welfare Reform Responsible for 
Low-Skilled Women's Declining Health Insurance Coverage in the 1990s?” Journal of Human Resources 41(3): 495-528.

Dye, Jane Lawler, 2008. “Fertility of American Women: June 2008”, Current Population Reports, P20-563, U.S. Census Bureau, Washington, DC.

Fix, Michael and Jeffrey S. Passel. 1999. "Trends in Noncitizens' and Citizens' Use of Public Benefits Following Welfare Reform: 1994-97.” Research report, March. Washington, DC: The Urban Institute. Available online at: http://www.urban.org/url.cfm?ID=408086.

Fix, Michael, and Wendy Zimmermann. 1998. "The Legacies of Welfare Reform's Immigrant Restrictions.” Interpreter Releases, November 16.

Graefe, D. G. DeJong, M. Hall, S. Sturgeon and J. Van Eerden. 2008. "Immigrants' TANF Eligibility, 1996-2003: What Explains the New Across-State Inequalities?” International Migration Review 42(1): 89-133.

Griswold, D. 2012. “Immigration and the Welfare State”, Cato Journal, 32(1): 159-174.

Haider, Steven J., Robert F. Schoeni, Yuhua Bao, and Caroline Danielson. 2004. "Immigrants, welfare reform, and the economy.” Journal of Policy Analysis and Management 23(4): 745-764.

Haskins, R. 2006. Work over Welfare: The Inside Story of the 1996 Welfare Reform Law. Washington, DC: Brookings Institution Press.

Kalil, A. and K. Ziol-Guest. 2009. "Welfare Reform and Health Among the Children of Immigrants". In J.P. Ziliak, Welfare Reform and Its Long-Term Consequences for America's Poor (pp. 308-336). New York: Cambridge University Press.

Kaestner, Robert and Neeraj Kaushal 2007. "Welfare Reform and Immigrants: Does the Fiveyear Ban Matter?”, in Barry R. Chiswick (ed.) Immigration (Research in Labor Economics, Volume 27), Emerald Group Publishing Limited, pp.311-347

Kaushal, Neeraj, and Robert Kaestner. 2005. "Welfare reform and health insurance of immigrants.” Health Services Research 40(3): 697-722.

Lurie, Ithai Zvi. 2008. "Welfare reform and the decline in the health-insurance coverage of children of non-permanent residents.” Journal of health economics 27(3): 786-793.

Mazzolari, F. 2004. "Effects of Welfare Reform on Immigrants' Welfare Participation: How ‘Chilling' are They?” Unpublished manuscript. Available online at: http://www.economics.uci.edu/fmazzola/Research/Mazzolari chilling.pdf.

Plotnick, R. and R. Winters 1985. "A Politico-Economic Theory of Income Redistribution.” American Political Science Review 79(2):458-473. 
Sevak P. and L. Schmidt. 2008. "Immigrant-Native Fertility and Mortality Differentials in the United States.”

Soss, J., S. Schram, T. Vartanian, and E. O’Brien. 2001. "Setting the Terms of Relief: Explaining State Policy Choices in the Devolution Revolution." American Journal of Political Science 45(2): 378-395.

Watson, Tara. 2010. "Inside the refrigerator: Immigration enforcement and chilling effects in Medicaid participation.” WP No. 16278, National Bureau of Economic Research.

Zimmermann,W.,Tumlin, K.C., 1999. "Patchwork Policies: State Assistance for Immigrants under Welfare Reform.” Occasional Paper No. 24, Urban Institute, Washington, DC. 
Table 1

Weighted Share of Women Giving Birth by Immigration Status and Hispanic Ethnicity

\begin{tabular}{lcccccc}
\hline \multirow{2}{*}{ Immigration Status } & \multicolumn{2}{c}{ All } & \multicolumn{2}{c}{ Hispanic } & \multicolumn{2}{c}{ Non-Hispanic } \\
\cline { 2 - 7 } & Mean & Obs. & Mean & Obs. & Mean & Obs. \\
\hline Native & 9.03 & 108,407 & 10.97 & 6,361 & 8.88 & 102,046 \\
Naturalized Immigrant & 11.67 & 3,610 & 13.99 & 1,108 & 10.46 & 2,502 \\
Foreign-born Non-citizens & 13.60 & 9,289 & 15.61 & 4,491 & 11.23 & 4,798 \\
\hline
\end{tabular}


Table 2: Shares of Women Giving Birth

\begin{tabular}{|c|c|c|c|c|c|c|c|c|c|c|}
\hline & \multicolumn{3}{|c|}{ States with Cutbacks } & \multicolumn{3}{|c|}{ States without Cutbacks } & \multirow{2}{*}{$\begin{array}{c}\text { DD } \\
\text { (DT-DC) }\end{array}$} & \multirow{2}{*}{$\begin{array}{c}\text { DDD } \\
\text { (DD Panel A- } \\
\text { DD Panel C) }\end{array}$} & \multirow{2}{*}{$\begin{array}{c}\text { DDD } \\
\text { (DD Panel A- } \\
\text { DD Panel D) }\end{array}$} & \multirow{2}{*}{$\begin{array}{c}\text { DDD } \\
\text { (DD Panel A- } \\
\text { DD Panel E) }\end{array}$} \\
\hline & Post & Pre & DT & Post & Pre & DC & & & & \\
\hline \multicolumn{11}{|c|}{ Panel A: Hispanic Immigrants } \\
\hline Shares & $\begin{array}{c}0.131 \\
(0.031)\end{array}$ & $\begin{array}{c}0.168 \\
(0.420)\end{array}$ & $\begin{array}{l}-0.038 \\
(0.059)\end{array}$ & $\begin{array}{c}0.130 \\
(0.012)\end{array}$ & $\begin{array}{c}0.063 \\
(0.009)\end{array}$ & $\begin{array}{c}0.066^{* * *} \\
(0.016)\end{array}$ & $\begin{array}{c}-0.103^{* *} \\
(0.056)\end{array}$ & $\begin{array}{c}-0.094^{* * *} \\
(0.004)\end{array}$ & $\begin{array}{c}-0.094 * * \\
(0.045)\end{array}$ & $\begin{array}{c}-0.102 * * \\
(0.060)\end{array}$ \\
\hline $\mathrm{N}$ & 123 & 79 & 202 & 743 & 714 & 1,457 & 1,659 & 30,357 & 32,979 & 4,281 \\
\hline \multicolumn{11}{|c|}{ Panel B: All Immigrants } \\
\hline Shares & $\begin{array}{c}0.105 \\
(0.021)\end{array}$ & $\begin{array}{c}0.116 \\
(0.026)\end{array}$ & $\begin{array}{c}-0.011 \\
(0.034)\end{array}$ & $\begin{array}{c}0.108 \\
(0.008)\end{array}$ & $\begin{array}{c}0.057 \\
(0.006)\end{array}$ & $\begin{array}{c}0.052 * * * \\
(0.011)\end{array}$ & $\begin{array}{c}-0.063 * * \\
(0.034)\end{array}$ & $\begin{array}{c}-0.053 * \\
(0.035)\end{array}$ & $\begin{array}{c}-0.054 * \\
(0.036)\end{array}$ & \\
\hline $\mathrm{N}$ & 202 & 158 & 360 & 1,218 & 1,332 & 2,550 & 2,910 & 31,608 & 34,230 & \\
\hline \multicolumn{11}{|c|}{ Panel C: Non-Hispanic Natives } \\
\hline Shares & $\begin{array}{c}0.097 \\
(0.004)\end{array}$ & $\begin{array}{c}0.056 \\
(0.003)\end{array}$ & $\begin{array}{c}0.041 * * * \\
(0.005)\end{array}$ & $\begin{array}{c}0.093 \\
(0.003)\end{array}$ & $\begin{array}{c}0.043 \\
(0.002)\end{array}$ & $\begin{array}{c}0.050 * * * \\
(0.003)\end{array}$ & $\begin{array}{c}-0.009 \\
(0.007)\end{array}$ & & & \\
\hline $\mathrm{N}$ & 4,815 & 5,787 & 10,602 & 8,363 & 9,733 & 18,100 & 28,698 & & & \\
\hline \multicolumn{11}{|c|}{ Panel D: All Natives } \\
\hline Shares & $\begin{array}{c}0.099 \\
(0.004)\end{array}$ & $\begin{array}{c}0.057 \\
(0.003)\end{array}$ & $\begin{array}{c}0.042^{* * * *} \\
(0.005)\end{array}$ & $\begin{array}{c}0.096 \\
(0.003)\end{array}$ & $\begin{array}{c}0.045 \\
(0.002)\end{array}$ & $\begin{array}{c}0.051^{* * * *} \\
(0.004)\end{array}$ & $\begin{array}{c}-0.008 \\
(0.006)\end{array}$ & & & \\
\hline $\mathrm{N}$ & 5,128 & 5,993 & 11,121 & 9,440 & 10,761 & 20,199 & 31,320 & & & \\
\hline \multicolumn{11}{|c|}{ Panel E: Hispanic Natives } \\
\hline Shares & $\begin{array}{c}0.144 \\
(0.019)\end{array}$ & $\begin{array}{c}0.087 \\
(0.019)\end{array}$ & $\begin{array}{c}0.057 * * \\
(0.030)\end{array}$ & $\begin{array}{c}0.117 \\
(0.009)\end{array}$ & $\begin{array}{c}0.059 \\
(0.007)\end{array}$ & $\begin{array}{c}0.058^{* * * *} \\
(0.012)\end{array}$ & $\begin{array}{l}-0.001 \\
(0.034)\end{array}$ & & & \\
\hline $\mathrm{N}$ & 313 & 206 & 519 & 1,077 & 1,026 & 2,103 & 1,659 & & & \\
\hline
\end{tabular}

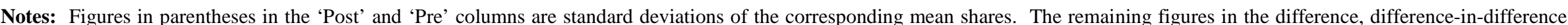

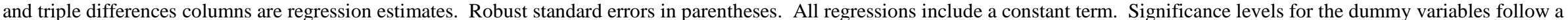
one-tail test. ${ }^{* * *} \mathrm{p}<0.01,{ }^{* *} \mathrm{p}<0.05,{ }^{*} \mathrm{p}<0.1$. 
Table 3

Dependent Variable: Likelihood of Giving Birth

\begin{tabular}{|c|c|c|c|c|}
\hline & (1) & $(2)$ & (3) & (4) \\
\hline Model Specification & Baseline & $\begin{array}{c}\text { Baseline } \\
\text { With Few controls }\end{array}$ & Extended Controls & $\begin{array}{l}\text { Unemployment, } \\
\text { State/Year FE, } \\
\text { State-Time Trend }\end{array}$ \\
\hline \multicolumn{5}{|c|}{ Panel A: Non-Hispanic Natives and Hispanic Immigrants } \\
\hline Cutbacks*Post-PRWORA*Immigrant & $\begin{array}{c}-0.094 * * \\
(0.049)\end{array}$ & $\begin{array}{c}-0.093 * * \\
(0.049)\end{array}$ & $\begin{array}{c}-0.068 * * \\
(0.041)\end{array}$ & $\begin{array}{c}-0.092 * * \\
(0.047)\end{array}$ \\
\hline Observations & 30,357 & 30,357 & 29,962 & 29,962 \\
\hline R-squared & 0.010 & 0.016 & 0.115 & 0.125 \\
\hline \multicolumn{5}{|c|}{ Panel B: All Natives and Hispanic Immigrants } \\
\hline Cutbacks*Post-PRWORA*Immigrant & $\begin{array}{c}-0.094^{* *} \\
(0.049)\end{array}$ & $\begin{array}{c}-0.093^{* *} \\
(0.049)\end{array}$ & $\begin{array}{l}-0.068 * \\
(0.043)\end{array}$ & $\begin{array}{c}-0.080 * * \\
(0.046)\end{array}$ \\
\hline Observations & 32,979 & 32,979 & 32,559 & 32,559 \\
\hline R-squared & 0.010 & 0.016 & 0.115 & 0.124 \\
\hline \multicolumn{5}{|c|}{ Panel C: Non-Hispanic Natives and All Immigrants } \\
\hline Cutbacks*Post-PRWORA*Immigrant & $\begin{array}{c}-0.053^{* *} \\
(0.032)\end{array}$ & $\begin{array}{c}-0.052 * * \\
(0.031)\end{array}$ & $\begin{array}{l}-0.031 \\
(0.029)\end{array}$ & $\begin{array}{l}-0.043 * \\
(0.030)\end{array}$ \\
\hline Observations & 31,608 & 31,608 & 31,194 & 31,194 \\
\hline R-squared & 0.009 & 0.016 & 0.114 & 0.124 \\
\hline \multicolumn{5}{|l|}{ Panel D: All Natives and All Immigrants } \\
\hline Cutbacks*Post-PRWORA*Immigrant & $\begin{array}{l}-0.054 * \\
(0.033)\end{array}$ & $\begin{array}{l}-0.052 * \\
(0.032)\end{array}$ & $\begin{array}{l}-0.031 \\
(0.031)\end{array}$ & $\begin{array}{l}-0.037 \\
(0.031)\end{array}$ \\
\hline Observations & 34,230 & 34,230 & 33,791 & 33,791 \\
\hline R-squared & 0.009 & 0.016 & 0.114 & 0.123 \\
\hline \multicolumn{5}{|c|}{ Panel E: Hispanic Natives and Hispanic Immigrants } \\
\hline Cutbacks*Post-PRWORA*Immigrant & $\begin{array}{c}-0.102 * * \\
(0.060)\end{array}$ & $\begin{array}{c}-0.101^{* *} \\
(0.059)\end{array}$ & $\begin{array}{l}-0.073 \\
(0.060)\end{array}$ & $\begin{array}{l}-0.071 \\
(0.059)\end{array}$ \\
\hline Observations & 4,281 & 4,281 & 4,230 & 4,230 \\
\hline R-squared & 0.012 & 0.012 & 0.101 & 0.121 \\
\hline
\end{tabular}

Notes: Specification (1) includes no controls. Specification (2) adds age, race and ethnicity to specification (1). Specification (3) adds educational attainment, no. of children, and a set of arrival cohort dummies to specification (2). Finally, specification (4) further includes the state unemployment rate, as well as state and year fixed effects, and a state-time trend to specification (3). All regressions include a constant term. Robust standard errors in parentheses. Significance levels for the dummy variables follow a one-tail test. ${ }^{* * *} \mathrm{p}<0.01, * * \mathrm{p}<0.05, * \mathrm{p}<0.1$. 
Table 4

Dependent Variable: Likelihood of Giving Birth

\begin{tabular}{|c|c|c|c|c|}
\hline & (1) & (2) & (3) & $(4)$ \\
\hline Model Specification & Baseline & $\begin{array}{l}\text { Baseline } \\
\text { With Few } \\
\text { controls }\end{array}$ & $\begin{array}{c}\text { Extended } \\
\text { Controls }\end{array}$ & $\begin{array}{l}\text { Unemployment, } \\
\text { State/Year FE, } \\
\text { State-Time Trend }\end{array}$ \\
\hline \multicolumn{5}{|l|}{ Panel A: Non-Hispanic Natives and Hispanic Immigrants } \\
\hline Cutbacks*Post-PRWORA*Naturalized Immigrant & $\begin{array}{c}-0.065 \\
(0.126)\end{array}$ & $\begin{array}{c}-0.061 \\
(0.127)\end{array}$ & $\begin{array}{c}-0.033 \\
(0.115)\end{array}$ & $\begin{array}{l}-0.051 \\
(0.120)\end{array}$ \\
\hline Cutbacks*Post-PRWORA*Foreign-born Non-citizen & $\begin{array}{c}-0.105^{* *} \\
(0.055)\end{array}$ & $\begin{array}{c}-0.105^{* *} \\
(0.055)\end{array}$ & $\begin{array}{c}-0.081^{* *} \\
(0.047)\end{array}$ & $\begin{array}{c}-0.106 * * \\
(0.052)\end{array}$ \\
\hline Observations & 30,357 & 30,357 & 29,962 & 29,962 \\
\hline R-squared & 0.010 & 0.016 & 0.115 & 0.125 \\
\hline \multicolumn{5}{|l|}{ Panel B: All Natives and Hispanic Immigrants } \\
\hline Cutbacks*Post-PRWORA*Naturalized Immigrant & $\begin{array}{c}-0.065 \\
(0.126)\end{array}$ & $\begin{array}{c}-0.062 \\
(0.126)\end{array}$ & $\begin{array}{c}-0.034 \\
(0.115)\end{array}$ & $\begin{array}{c}-0.045 \\
(0.118)\end{array}$ \\
\hline Cutbacks*Post-PRWORA*Foreign-born Non-citizen & $\begin{array}{c}-0.106 * * \\
(0.055)\end{array}$ & $\begin{array}{c}-0.105^{* *} \\
(0.056)\end{array}$ & $\begin{array}{c}-0.081^{* *} \\
(0.048)\end{array}$ & $\begin{array}{c}-0.094 * * \\
(0.051)\end{array}$ \\
\hline Observations & 32,979 & 32,979 & 32,559 & 32,559 \\
\hline R-squared & 0.010 & 0.016 & 0.115 & 0.124 \\
\hline \multicolumn{5}{|l|}{ Panel C: Non-Hispanic Natives and All Immigrants } \\
\hline Cutbacks*Post-PRWORA*Naturalized Immigrant & $\begin{array}{c}-0.006 \\
(0.061)\end{array}$ & $\begin{array}{c}-0.004 \\
(0.065)\end{array}$ & $\begin{array}{l}-0.013 \\
(0.058)\end{array}$ & $\begin{array}{c}-0.018 \\
(0.058)\end{array}$ \\
\hline Cutbacks*Post-PRWORA*Foreign-born Non-citizen & $\begin{array}{c}-0.066^{* *} \\
(0.037)\end{array}$ & $\begin{array}{c}-0.064^{* *} \\
(0.036)\end{array}$ & $\begin{array}{c}-0.036 \\
(0.033)\end{array}$ & $\begin{array}{l}-0.050 * \\
(0.035)\end{array}$ \\
\hline Observations & 31,608 & 31,608 & 31,194 & 31,194 \\
\hline R-squared & 0.009 & 0.016 & 0.114 & 0.124 \\
\hline \multicolumn{5}{|l|}{ Panel D: All Natives and All Immigrants } \\
\hline Cutbacks*Post-PRWORA*Naturalized Immigrant & $\begin{array}{l}-0.007 \\
(0.061)\end{array}$ & $\begin{array}{c}-0.005 \\
(0.063)\end{array}$ & $\begin{array}{l}-0.016 \\
(0.059)\end{array}$ & $\begin{array}{c}-0.018 \\
(0.060)\end{array}$ \\
\hline Cutbacks*Post-PRWORA*Foreign-born Non-citizen & $\begin{array}{c}-0.066^{* *} \\
(0.038)\end{array}$ & $\begin{array}{c}-0.064^{* *} \\
(0.037)\end{array}$ & $\begin{array}{l}-0.035 \\
(0.034)\end{array}$ & $\begin{array}{l}-0.042 \\
(0.035)\end{array}$ \\
\hline Observations & 34,230 & 34,230 & 33,791 & 33,791 \\
\hline R-squared & 0.009 & 0.016 & 0.115 & 0.123 \\
\hline \multicolumn{5}{|l|}{ Panel E: Hispanic Natives and Hispanic Immigrants } \\
\hline Cutbacks*Post-PRWORA*Naturalized Immigrant & $\begin{array}{l}-0.073 \\
(0.122)\end{array}$ & $\begin{array}{c}-0.073 \\
(0.124)\end{array}$ & $\begin{array}{l}-0.045 \\
(0.114)\end{array}$ & $\begin{array}{l}-0.052 \\
(0.118)\end{array}$ \\
\hline Cutbacks*Post-PRWORA*Foreign-born Non-citizen & $\begin{array}{c}-0.114^{* *} \\
(0.066)\end{array}$ & $\begin{array}{c}-0.112^{* *} \\
(0.065)\end{array}$ & $\begin{array}{c}-0.086 * \\
(0.064)\end{array}$ & $\begin{array}{l}-0.078 \\
(0.061)\end{array}$ \\
\hline Observations & 4,281 & 4,281 & 4,230 & 4,230 \\
\hline R-squared & 0.012 & 0.013 & 0.102 & 0.123 \\
\hline
\end{tabular}

Notes: Specification (1) includes no controls. Specification (2) adds age, race and ethnicity to specification (1). Specification (3) adds educational attainment, no. of children, and a set of arrival cohort dummies to specification (2). Finally, specification (4) further includes the state unemployment rate, as well as state and year fixed effects, and a state-time trend to specification (3). All regressions include a constant term. Robust standard errors in parentheses. Significance levels for the dummy variables follow a one-tail test. ${ }^{* * *} \mathrm{p}<0.01,{ }^{* *} \mathrm{p}<0.05,{ }^{*} \mathrm{p}<0.1$. 
Table 5

Dependent Variable: Employment Likelihood

\begin{tabular}{|c|c|c|c|c|}
\hline & (1) & $(2)$ & (3) & (4) \\
\hline Model Specification & Baseline & $\begin{array}{c}\text { Baseline } \\
\text { With Few controls }\end{array}$ & Extended Controls & $\begin{array}{l}\text { Unemployment, } \\
\text { State/Year FE, } \\
\text { State-Time Trend }\end{array}$ \\
\hline \multicolumn{5}{|c|}{ Panel A: Non-Hispanic Natives and Hispanic Immigrants } \\
\hline Cutbacks*Post-PRWORA*Immigrant & $\begin{array}{c}0.117 * * \\
(0.063)\end{array}$ & $\begin{array}{c}0.105^{* *} \\
(0.060)\end{array}$ & $\begin{array}{l}0.103^{*} \\
(0.065)\end{array}$ & $\begin{array}{c}0.113 * * \\
(0.068)\end{array}$ \\
\hline $\begin{array}{l}\text { Observations } \\
\text { R-squared }\end{array}$ & 30,357 & 30,357 & 29,962 & 29,962 \\
\hline \multicolumn{5}{|c|}{ Panel B: All Natives and Hispanic Immigrants } \\
\hline Cutbacks*Post-PRWORA*Immigrant & $\begin{array}{c}0.117^{* *} \\
(0.064)\end{array}$ & $\begin{array}{c}0.104 * * \\
(0.060)\end{array}$ & $\begin{array}{l}0.102 * \\
(0.065)\end{array}$ & $\begin{array}{c}0.113 * * \\
(0.067)\end{array}$ \\
\hline Observations & 32,979 & 32,979 & 32,559 & 32,559 \\
\hline R-squared & 0.002 & 0.084 & 0.145 & 0.158 \\
\hline \multicolumn{5}{|c|}{ Panel C: Non-Hispanic Natives and All Immigrants } \\
\hline Cutbacks*Post-PRWORA*Immigrant & $\begin{array}{c}0.138 * * * \\
(0.046)\end{array}$ & $\begin{array}{c}0.112 * * * \\
(0.046)\end{array}$ & $\begin{array}{c}0.088 * * \\
(0.047)\end{array}$ & $\begin{array}{c}0.094 * * \\
(0.051)\end{array}$ \\
\hline Observations & 31,608 & 31,608 & 31,194 & 31,194 \\
\hline R-squared & 0.004 & 0.080 & 0.140 & 0.154 \\
\hline \multicolumn{5}{|l|}{ Panel D: All Natives and All Immigrants } \\
\hline Cutbacks*Post-PRWORA*Immigrant & $\begin{array}{c}0.138 * * * \\
(0.048)\end{array}$ & $\begin{array}{c}0.112 * * \\
(0.048)\end{array}$ & $\begin{array}{c}0.089 * * \\
(0.049)\end{array}$ & $\begin{array}{c}0.096 * * \\
(0.051)\end{array}$ \\
\hline Observations & 34,230 & 34,230 & 33,791 & 33,791 \\
\hline R-squared & 0.003 & 0.085 & 0.145 & 0.158 \\
\hline \multicolumn{5}{|c|}{ Panel E: Hispanic Natives and Hispanic Immigrants } \\
\hline Cutbacks*Post-PRWORA*Immigrant & $\begin{array}{c}0.158 * * \\
(0.082)\end{array}$ & $\begin{array}{c}0.149 * * \\
(0.075)\end{array}$ & $\begin{array}{l}0.124 * \\
(0.079)\end{array}$ & $\begin{array}{c}0.144^{* *} \\
(0.075)\end{array}$ \\
\hline Observations & 4,281 & 4,281 & 4,230 & 4,230 \\
\hline R-squared & 0.014 & 0.095 & 0.152 & 0.190 \\
\hline
\end{tabular}

Notes: Specification (1) includes no controls. Specification (2) adds age, race and ethnicity to specification (1). Specification (3) adds educational attainment, no. of children, and a set of arrival cohort dummies to specification (2). Finally, specification (4) further includes the state unemployment rate, as well as state and year fixed effects, and a state-time trend to specification (3). All regressions include a constant term. Robust standard errors in parentheses. Significance levels for the dummy variables follow a one-tail test. ${ }^{* * *} \mathrm{p}<0.01, * * \mathrm{p}<0.05, * \mathrm{p}<0.1$. 
Table 6

Dependent Variable: Employment Likelihood

\begin{tabular}{|c|c|c|c|c|}
\hline & (1) & (2) & (3) & (4) \\
\hline Model Specification & Baseline & $\begin{array}{l}\text { Baseline } \\
\text { With Few } \\
\text { controls } \\
\end{array}$ & $\begin{array}{l}\text { Extended } \\
\text { Controls }\end{array}$ & $\begin{array}{l}\text { Unemployment, } \\
\text { State/Year FE, } \\
\text { State-Time Trend }\end{array}$ \\
\hline \multicolumn{5}{|c|}{ Panel A: Non-Hispanic Natives and Hispanic Immigrants } \\
\hline Cutbacks*Post-PRWORA*Naturalized Immigrant & $\begin{array}{l}-0.133 \\
(0.181)\end{array}$ & $\begin{array}{c}-0.127 \\
(0.202)\end{array}$ & $\begin{array}{l}-0.069 \\
(0.195)\end{array}$ & $\begin{array}{c}-0.072 \\
(0.194)\end{array}$ \\
\hline Cutbacks*Post-PRWORA*Foreign-born Non-citizen & $\begin{array}{c}0.156^{* * *} \\
(0.054)\end{array}$ & $\begin{array}{c}0.141^{* * *} \\
(0.050)\end{array}$ & $\begin{array}{c}0.127 * * \\
(0.059)\end{array}$ & $\begin{array}{c}0.140 * * \\
(0.064)\end{array}$ \\
\hline Observations & 30,357 & 30,357 & 29,962 & 29,962 \\
\hline R-squared & 0.003 & 0.078 & 0.139 & 0.152 \\
\hline \multicolumn{5}{|l|}{ Panel B: All Natives and Hispanic Immigrants } \\
\hline Cutbacks*Post-PRWORA*Naturalized Immigrant & $\begin{array}{l}-0.133 \\
(0.181)\end{array}$ & $\begin{array}{c}-0.129 \\
(0.201)\end{array}$ & $\begin{array}{c}-0.064 \\
(0.198)\end{array}$ & $\begin{array}{c}-0.073 \\
(0.197)\end{array}$ \\
\hline Cutbacks*Post-PRWORA*Foreign-born Non-citizen & $\begin{array}{c}0.156^{* * *} \\
(0.055)\end{array}$ & $\begin{array}{c}0.141^{* * *} \\
(0.050)\end{array}$ & $\begin{array}{c}0.125 * * \\
(0.059)\end{array}$ & $\begin{array}{c}0.139 * * \\
(0.063)\end{array}$ \\
\hline Observations & 32,979 & 32,979 & 32,559 & 32,559 \\
\hline R-squared & 0.003 & 0.084 & 0.145 & 0.158 \\
\hline \multicolumn{5}{|l|}{ Panel C: Non-Hispanic Natives and All Immigrants } \\
\hline Cutbacks*Post-PRWORA*Naturalized Immigrant & $\begin{array}{c}0.003 \\
(0.118)\end{array}$ & $\begin{array}{c}0.003 \\
(0.118)\end{array}$ & $\begin{array}{c}0.066 \\
(0.125)\end{array}$ & $\begin{array}{c}0.051 \\
(0.130)\end{array}$ \\
\hline Cutbacks*Post-PRWORA*Foreign-born Non-citizen & $\begin{array}{c}0.162 * * * \\
(0.051)\end{array}$ & $\begin{array}{c}0.128 * * \\
(0.056)\end{array}$ & $\begin{array}{l}0.087^{*} \\
(0.061)\end{array}$ & $\begin{array}{l}0.098 * \\
(0.063)\end{array}$ \\
\hline Observations & 31,608 & 31,608 & 31,194 & 31,194 \\
\hline R-squared & 0.005 & 0.081 & 0.140 & 0.154 \\
\hline \multicolumn{5}{|l|}{ Panel D: All Natives and All Immigrants } \\
\hline Cutbacks*Post-PRWORA*Naturalized Immigrant & $\begin{array}{c}0.003 \\
(0.118)\end{array}$ & $\begin{array}{c}0.003 \\
(0.118)\end{array}$ & $\begin{array}{c}0.074 \\
(0.128)\end{array}$ & $\begin{array}{c}0.053 \\
(0.135)\end{array}$ \\
\hline Cutbacks*Post-PRWORA*Foreign-born Non-citizen & $\begin{array}{c}0.162^{* * *} \\
(0.053)\end{array}$ & $\begin{array}{c}0.129 * * \\
(0.058)\end{array}$ & $\begin{array}{l}0.085^{*} \\
(0.062)\end{array}$ & $\begin{array}{l}0.098^{*} \\
(0.062)\end{array}$ \\
\hline Observations & 34,230 & 34,230 & 33,791 & 33,791 \\
\hline R-squared & 0.004 & 0.086 & 0.145 & 0.158 \\
\hline \multicolumn{5}{|l|}{ Panel E: Hispanic Natives and Hispanic Immigrants } \\
\hline Cutbacks*Post-PRWORA*Naturalized Immigrant & $\begin{array}{c}-0.092 \\
(0.176)\end{array}$ & $\begin{array}{c}-0.095 \\
(0.196)\end{array}$ & $\begin{array}{l}-0.068 \\
(0.187)\end{array}$ & $\begin{array}{l}-0.082 \\
(0.188)\end{array}$ \\
\hline Cutbacks*Post-PRWORA*Foreign-born Non-citizen & $\begin{array}{c}0.197 * * * \\
(0.081)\end{array}$ & $\begin{array}{c}0.189 * * * \\
(0.069)\end{array}$ & $\begin{array}{c}0.152 * * \\
(0.078)\end{array}$ & $\begin{array}{c}0.184^{* * *} \\
(0.068)\end{array}$ \\
\hline Observations & 4,281 & 4,281 & 4,230 & 4,230 \\
\hline R-squared & 0.017 & 0.096 & 0.152 & 0.190 \\
\hline
\end{tabular}

Notes: Specification (1) includes no controls. Specification (2) adds age, race and ethnicity to specification (1). Specification (3) adds educational attainment, no. of children, and a set of arrival cohort dummies to specification (2). Finally, specification (4) further includes the state unemployment rate, as well as state and year fixed effects, and a state-time trend to specification (3). All regressions include a constant term. Robust standard errors in parentheses. Significance levels for the dummy variables follow a one-tail test. ${ }^{* * *} \mathrm{p}<0.01,{ }^{* *} \mathrm{p}<0.05,{ }^{*} \mathrm{p}<0.1$. 
Table 7

Robustness Check for Pre-trends: Falsified Policy Timing

Dependent Variable: Likelihood of Giving Birth

\begin{tabular}{|c|c|c|c|c|}
\hline & (1) & (2) & (3) & (4) \\
\hline Model Specification & Baseline & $\begin{array}{c}\text { Baseline } \\
\text { With Few controls }\end{array}$ & Extended Controls & $\begin{array}{c}\text { Unemployment, } \\
\text { State/Year FE, } \\
\text { State-Time Trend }\end{array}$ \\
\hline \multicolumn{5}{|c|}{ Panel A: Non-Hispanic Natives and Hispanic Immigrants } \\
\hline Cutbacks*Post-PRWORA*Immigrant & $\begin{array}{c}0.142 * * \\
(0.077)\end{array}$ & $\begin{array}{c}0.138 * * \\
(0.075)\end{array}$ & $\begin{array}{l}0.150 * * \\
(0.072)\end{array}$ & $\begin{array}{c}0.179 * * \\
(0.078)\end{array}$ \\
\hline Observations & 16,313 & 16,313 & 16,160 & 16,160 \\
\hline R-squared & 0.019 & 0.029 & 0.106 & 0.113 \\
\hline \multicolumn{5}{|c|}{ Panel B: All Natives and Hispanic Immigrants } \\
\hline Cutbacks*Post-PRWORA*Immigrant & $\begin{array}{c}0.147 * * \\
(0.076)\end{array}$ & $\begin{array}{l}0.142 * * \\
(0.074)\end{array}$ & $\begin{array}{l}0.152 * * \\
(0.071)\end{array}$ & $\begin{array}{c}0.178 * * * \\
(0.073)\end{array}$ \\
\hline Observations & 17,545 & 17,545 & 17,381 & 17,381 \\
\hline R-squared & 0.019 & 0.029 & 0.105 & 0.111 \\
\hline \multicolumn{5}{|c|}{ Panel C: Non-Hispanic Natives and All Immigrants } \\
\hline Cutbacks*Post-PRWORA*Immigrant & $\begin{array}{c}0.010 \\
(0.046)\end{array}$ & $\begin{array}{c}0.009 \\
(0.044)\end{array}$ & $\begin{array}{c}0.020 \\
(0.043)\end{array}$ & $\begin{array}{c}0.031 \\
(0.047)\end{array}$ \\
\hline Observations & 17,010 & 17,010 & 16,851 & 16,851 \\
\hline R-squared & 0.017 & 0.028 & 0.104 & 0.111 \\
\hline \multicolumn{5}{|c|}{ Panel D: All Natives and All Immigrants } \\
\hline Cutbacks*Post-PRWORA*Immigrant & $\begin{array}{c}0.014 \\
(0.046)\end{array}$ & $\begin{array}{c}0.011 \\
(0.044)\end{array}$ & $\begin{array}{c}0.023 \\
(0.044)\end{array}$ & $\begin{array}{c}0.035 \\
(0.045)\end{array}$ \\
\hline Observations & 18,242 & 18,242 & 18,072 & 18,072 \\
\hline R-squared & 0.018 & 0.028 & 0.104 & 0.110 \\
\hline \multicolumn{5}{|c|}{ Panel E: Hispanic Natives and Hispanic Immigrants } \\
\hline Cutbacks*Post-PRWORA*Immigrant & $\begin{array}{c}0.206 * * * \\
(0.065)\end{array}$ & $\begin{array}{c}0.206^{* * * *} \\
(0.065)\end{array}$ & $\begin{array}{c}0.205^{* * *} \\
(0.064)\end{array}$ & $\begin{array}{c}0.221^{* * * *} \\
(0.052)\end{array}$ \\
\hline Observations & 2,025 & 2,025 & 2,009 & 2,009 \\
\hline R-squared & 0.026 & 0.031 & 0.100 & 0.123 \\
\hline
\end{tabular}

Notes: The sample is limited to the years 1994 and 1995. Specification (1) includes no controls. Specification (2) adds age, race and ethnicity to specification (1). Specification (3) adds educational attainment, no. of children, and a set of arrival cohort dummies to specification (2). Finally, specification (4) further includes the state unemployment rate, as well as state and year fixed effects, and a state-time trend to specification (3). All regressions include a constant term. Robust standard errors in parentheses. Significance levels for the dummy variables follow a one-tail test. ${ }^{* * *} \mathrm{p}<0.01,{ }^{* *} \mathrm{p}<0.05,{ }^{*} \mathrm{p}<0.1$. 
Table 8

Robustness Check for Pre-trends: Falsified Policy Timing

Dependent Variable: Likelihood of Giving Birth

\begin{tabular}{|c|c|c|c|c|}
\hline & (1) & (2) & (3) & $(4)$ \\
\hline Model Specification & Baseline & $\begin{array}{l}\text { Baseline } \\
\text { With Few } \\
\text { controls } \\
\end{array}$ & $\begin{array}{l}\text { Extended } \\
\text { Controls }\end{array}$ & $\begin{array}{l}\text { Unemployment, } \\
\text { State/Year FE, } \\
\text { State-Time Trend }\end{array}$ \\
\hline \multicolumn{5}{|c|}{ Panel A: Non-Hispanic Natives and Hispanic Immigrants } \\
\hline Cutbacks*Post-PRWORA*Naturalized Immigrant & $\begin{array}{c}-0.150 \\
(0.183)\end{array}$ & $\begin{array}{c}-0.153 \\
(0.182)\end{array}$ & $\begin{array}{c}-0.147 \\
(0.189)\end{array}$ & $\begin{array}{c}-0.144 \\
(0.200)\end{array}$ \\
\hline Cutbacks*Post-PRWORA*Foreign-born Non-citizen & $\begin{array}{c}0.183 * * \\
(0.090)\end{array}$ & $\begin{array}{c}0.178 * * \\
(0.088)\end{array}$ & $\begin{array}{c}0.192 * * \\
(0.088)\end{array}$ & $\begin{array}{c}0.226 * * * \\
(0.094)\end{array}$ \\
\hline Observations & 16,313 & 16,313 & 16,160 & 16,160 \\
\hline R-squared & 0.019 & 0.030 & 0.106 & 0.113 \\
\hline \multicolumn{5}{|l|}{ Panel B: All Natives and Hispanic Immigrants } \\
\hline Cutbacks*Post-PRWORA*Naturalized Immigrant & $\begin{array}{l}-0.145 \\
(0.183)\end{array}$ & $\begin{array}{c}-0.148 \\
(0.182)\end{array}$ & $\begin{array}{c}-0.148 \\
(0.187)\end{array}$ & $\begin{array}{l}-0.137 \\
(0.193)\end{array}$ \\
\hline Cutbacks*Post-PRWORA*Foreign-born Non-citizen & $\begin{array}{c}0.187 * * \\
(0.089)\end{array}$ & $\begin{array}{c}0.183 * * \\
(0.087)\end{array}$ & $\begin{array}{c}0.195 * * \\
(0.087)\end{array}$ & $\begin{array}{c}0.223^{* * *} \\
(0.088)\end{array}$ \\
\hline Observations & 17,545 & 17,545 & 17,381 & 17,381 \\
\hline R-squared & 0.019 & 0.030 & 0.105 & 0.111 \\
\hline \multicolumn{5}{|l|}{ Panel C: Non-Hispanic Natives and All Immigrants } \\
\hline Cutbacks*Post-PRWORA*Naturalized Immigrant & $\begin{array}{c}-0.135 \\
(0.122)\end{array}$ & $\begin{array}{c}-0.140 \\
(0.115)\end{array}$ & $\begin{array}{c}-0.139 \\
(0.119)\end{array}$ & $\begin{array}{c}-0.143 \\
(0.121)\end{array}$ \\
\hline Cutbacks*Post-PRWORA*Foreign-born Non-citizen & $\begin{array}{c}0.037 \\
(0.058)\end{array}$ & $\begin{array}{c}0.037 \\
(0.055)\end{array}$ & $\begin{array}{c}0.049 \\
(0.055)\end{array}$ & $\begin{array}{c}0.064 \\
(0.061)\end{array}$ \\
\hline Observations & 17,010 & 17,010 & 16,851 & 16,851 \\
\hline R-squared & 0.018 & 0.028 & 0.105 & 0.111 \\
\hline \multicolumn{5}{|l|}{ Panel D: All Natives and All Immigrants } \\
\hline Cutbacks*Post-PRWORA*Naturalized Immigrant & $\begin{array}{l}-0.130 \\
(0.122)\end{array}$ & $\begin{array}{l}-0.139 \\
(0.118)\end{array}$ & $\begin{array}{l}-0.136 \\
(0.119)\end{array}$ & $\begin{array}{l}-0.136 \\
(0.121)\end{array}$ \\
\hline Cutbacks*Post-PRWORA*Foreign-born Non-citizen & $\begin{array}{c}0.041 \\
(0.058)\end{array}$ & $\begin{array}{c}0.039 \\
(0.055)\end{array}$ & $\begin{array}{c}0.052 \\
(0.056)\end{array}$ & $\begin{array}{c}0.067 \\
(0.057)\end{array}$ \\
\hline Observations & 18,242 & 18,242 & 18,072 & 18,072 \\
\hline R-squared & 0.018 & 0.028 & 0.104 & 0.110 \\
\hline \multicolumn{5}{|l|}{ Panel E: Hispanic Natives and Hispanic Immigrants } \\
\hline Cutbacks*Post-PRWORA*Naturalized Immigrant & $\begin{array}{c}-0.086 \\
(0.198)\end{array}$ & $\begin{array}{c}-0.085 \\
(0.197)\end{array}$ & $\begin{array}{c}-0.098 \\
(0.195)\end{array}$ & $\begin{array}{c}-0.030 \\
(0.187)\end{array}$ \\
\hline Cutbacks*Post-PRWORA*Foreign-born Non-citizen & $\begin{array}{c}0.247 * * * \\
(0.075)\end{array}$ & $\begin{array}{c}0.247 * * * \\
(0.075)\end{array}$ & $\begin{array}{c}0.248 * * * \\
(0.076)\end{array}$ & $\begin{array}{c}0.272 * * * \\
(0.063)\end{array}$ \\
\hline Observations & 2,025 & 2,025 & 2,009 & 2,009 \\
\hline R-squared & 0.028 & 0.033 & 0.102 & 0.126 \\
\hline
\end{tabular}

Notes: The sample is limited to the years 1994 and 1995. Specification (1) includes no controls. Specification (2) adds age, race and ethnicity to specification (1). Specification (3) adds educational attainment, no. of children, and a set of arrival cohort dummies to specification (2). Finally, specification (4) further includes the state unemployment rate, as well as state and year fixed effects, and a state-time trend to specification (3). All regressions include a constant term. Robust standard errors in parentheses. Significance levels for the dummy variables follow a one-tail test. ${ }^{* * *} \mathrm{p}<0.01,{ }^{* *} \mathrm{p}<0.05,{ }^{*} \mathrm{p}<0.1$. 
Table 9

Robustness Check for Endogeneity of Immigrant Location

\begin{tabular}{|c|c|c|c|c|c|c|}
\hline \multirow{2}{*}{$\begin{array}{l}\text { Dependent Variable: } \\
\text { Column: }\end{array}$} & \multicolumn{2}{|c|}{ Share of Immigrants } & \multicolumn{2}{|c|}{ Share of Foreign-born Naturalized } & \multicolumn{2}{|c|}{ Share of Foreign-born Non-citizens } \\
\hline & (1) & (2) & (3) & (4) & (5) & (6) \\
\hline Model Specification & 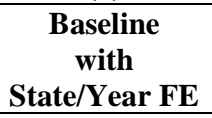 & $\begin{array}{c}\text { Baseline with } \\
\text { State/Year FE, } \\
\text { State-Time Trend }\end{array}$ & 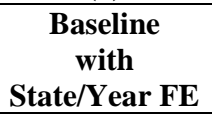 & $\begin{array}{c}\text { Baseline with } \\
\text { State/Year FE, } \\
\text { State-Time Trend }\end{array}$ & 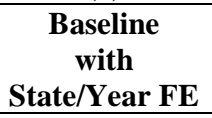 & $\begin{array}{c}\text { Baseline with } \\
\text { State/Year FE, } \\
\text { State-Time Trend }\end{array}$ \\
\hline Cutbacks*Post-PRWORA & $\begin{array}{l}-0.001 \\
(0.006)\end{array}$ & $\begin{array}{c}-0.002 \\
(0.010)\end{array}$ & $\begin{array}{l}-0.003 \\
(0.003)\end{array}$ & $\begin{array}{l}-0.004 \\
(0.006)\end{array}$ & $\begin{array}{c}0.002 \\
(0.005)\end{array}$ & $\begin{array}{c}0.003 \\
(0.008)\end{array}$ \\
\hline Post-PRWORA & $\begin{array}{c}0.015 * * * \\
(0.006)\end{array}$ & $\begin{array}{c}0.000 \\
(0.007)\end{array}$ & $\begin{array}{c}0.005^{* *} \\
(0.003)\end{array}$ & $\begin{array}{c}0.004 \\
(0.005)\end{array}$ & $\begin{array}{c}0.010^{* *} \\
(0.005)\end{array}$ & $\begin{array}{l}-0.004 \\
(0.006)\end{array}$ \\
\hline Cutbacks & $\begin{array}{c}-0.012^{* * * *} \\
(0.003)\end{array}$ & $\begin{array}{c}-0.011^{* *} \\
(0.005)\end{array}$ & $\begin{array}{l}-0.002 \\
(0.002)\end{array}$ & $\begin{array}{c}-0.008^{* * * *} \\
(0.003)\end{array}$ & $\begin{array}{c}-0.010^{* * * *} \\
(0.003)\end{array}$ & $\begin{array}{l}-0.003 \\
(0.004)\end{array}$ \\
\hline Observations & 200 & 200 & 200 & 200 & 200 & 200 \\
\hline R-squared & 0.963 & 0.983 & 0.892 & 0.953 & 0.949 & 0.978 \\
\hline
\end{tabular}

Notes: The unit of observation is the (state, year) cell. Specification (1) includes state and year fixed-effects. Specification (2) adds a state-time. All regressions include a constant term. Robust standard errors in parentheses. Significance levels for the dummy variables follow a one-tail test. $* * *$ $\mathrm{p}<0.01, * * \mathrm{p}<0.05, * \mathrm{p}<0.1$ 


\section{Appendix}

Table A

State-funded Assistance to Immigrants after 1996

\begin{tabular}{|c|c|c|}
\hline State & $\begin{array}{l}\text { Food Assistance or SSI to Pre- } \\
\text { enactment Immigrants }\end{array}$ & $\begin{array}{c}\text { TANF, Medicaid, Food Assistance, or } \\
\text { SSI to Post-enactment Immigrants } \\
\text { during 5-year Bar }\end{array}$ \\
\hline Alabama & No & No \\
\hline Alaska & No & No \\
\hline Arizona & No & No \\
\hline Arkansas & No & No \\
\hline California & Yes & Yes \\
\hline Colorado & No & Yes \\
\hline Connecticut & Yes & Yes \\
\hline Delaware & No & Yes \\
\hline District of Columbia & No & No \\
\hline Florida & Yes & No \\
\hline Georgia & No & Yes \\
\hline Hawaii & No & Yes \\
\hline Idaho & No & No \\
\hline Illinois & Yes & Yes \\
\hline Indiana & No & No \\
\hline Iowa & No & No \\
\hline Kansas & No & No \\
\hline Kentucky & No & No \\
\hline Louisiana & No & No \\
\hline Maine & Yes & Yes \\
\hline Maryland & Yes & Yes \\
\hline Massachusetts & Yes & Yes \\
\hline Michigan & No & No \\
\hline Minnesota & Yes & Yes \\
\hline Mississippi & No & No \\
\hline Missouri & Yes & Yes \\
\hline Montana & No & No \\
\hline Nebraska & Yes & Yes \\
\hline Nevada & No & No \\
\hline New Hampshire & Yes & No \\
\hline New Jersey & Yes & No \\
\hline New Mexico & No & No \\
\hline New York & Yes & No \\
\hline North Carolina & No & No \\
\hline North Dakota & No & No \\
\hline Ohio & Yes & No \\
\hline Oklahoma & No & No \\
\hline Oregon & Yes & Yes \\
\hline Pennsylvania & No & Yes \\
\hline Rhode Island & Yes & Yes \\
\hline South Carolina & No & No \\
\hline South Dakota & No & No \\
\hline Tennessee & No & Yes \\
\hline Texas & Yes & No \\
\hline Utah & No & Yes \\
\hline Vermont & No & Yes \\
\hline Virginia & No & Yes \\
\hline Washington & Yes & Yes \\
\hline West Virginia & No & No \\
\hline Wisconsin & Yes & Yes \\
\hline Wyoming & No & Yes \\
\hline
\end{tabular}

Source: Borjas (2003). 
Table B

Weighted Sample Descriptive Statistics

\begin{tabular}{|c|c|c|c|c|c|c|c|c|c|c|c|c|c|c|c|}
\hline \multirow{2}{*}{$\begin{array}{l}\text { Samples } \\
\text { Variables } \\
\end{array}$} & \multicolumn{3}{|c|}{$\begin{array}{c}\text { Non-Hispanic Natives \& } \\
\text { Hispanic Immigrants } \\
\text { Panel A }\end{array}$} & \multicolumn{3}{|c|}{$\begin{array}{c}\text { All Natives \& } \\
\text { Hispanic Immigrants } \\
\text { Panel B }\end{array}$} & \multicolumn{3}{|c|}{$\begin{array}{c}\text { Non-Hispanic Natives \& } \\
\text { All Immigrants } \\
\text { Panel C } \\
\end{array}$} & \multicolumn{3}{|c|}{$\begin{array}{c}\text { All Natives \& } \\
\text { All Immigrants } \\
\text { Panel D } \\
\end{array}$} & \multicolumn{3}{|c|}{$\begin{array}{c}\text { All Hispanic Natives \& } \\
\text { All Hispanics } \\
\text { Panel E } \\
\end{array}$} \\
\hline & Obs. & Mean & S.D. & Obs. & Mean & S.D. & Obs. & Mean & S.D. & Obs. & Mean & S.D. & Obs. & Mean & S.D. \\
\hline Giving Birth & 30,357 & 0.07 & 0.26 & 31,608 & 0.07 & 0.26 & 32,979 & 0.07 & 0.26 & 34,230 & 0.07 & 0.26 & 4,281 & 0.10 & 0.30 \\
\hline State with Cutbacks & 30,357 & 0.28 & 0.45 & 31,608 & 0.28 & 0.45 & 32,979 & 0.27 & 0.44 & 34,230 & 0.26 & 0.44 & 4,281 & 0.11 & 0.31 \\
\hline Post-PRWORA & 30,357 & 0.50 & 0.50 & 31,608 & 0.51 & 0.50 & 32,979 & 0.51 & 0.50 & 34,230 & 0.51 & 0.50 & 4,281 & 0.55 & 0.50 \\
\hline Immigrant & 30,357 & 0.06 & 0.25 & 31,608 & 0.10 & 0.30 & 32,979 & 0.06 & 0.23 & 34,230 & 0.09 & 0.29 & 4,281 & 0.39 & 0.49 \\
\hline Naturalized Immigrant & 30,357 & 0.01 & 0.09 & 31,608 & 0.02 & 0.12 & 32,979 & 0.01 & 0.08 & 34,230 & 0.01 & 0.12 & 4,281 & 0.05 & 0.21 \\
\hline Foreign-born Noncitizen & 30,357 & 0.06 & 0.23 & 31,608 & 0.08 & 0.28 & 32,979 & 0.05 & 0.22 & 34,230 & 0.08 & 0.27 & 4,281 & 0.34 & 0.47 \\
\hline Age & 30,357 & 24.93 & 9.29 & 31,608 & 24.99 & 9.31 & 32,979 & 24.80 & 9.25 & 34,230 & 24.86 & 9.27 & 4,281 & 25.07 & 9.00 \\
\hline White & 30,357 & 0.72 & 0.45 & 31,608 & 0.70 & 0.46 & 32,979 & 0.74 & 0.44 & 34,230 & 0.72 & 0.45 & 4,281 & 0.90 & 0.30 \\
\hline Black & 30,357 & 0.25 & 0.43 & 31,608 & 0.25 & 0.43 & 32,979 & 0.23 & 0.42 & 34,230 & 0.23 & 0.42 & 4,281 & 0.03 & 0.18 \\
\hline Other Non-White & 30,357 & 0.02 & 0.15 & 31,608 & 0.04 & 0.19 & 32,979 & 0.02 & 0.15 & 34,230 & 0.04 & 0.18 & 4,281 & 0.02 & 0.12 \\
\hline Hispanic & 30,357 & 0.06 & 0.25 & 31,608 & 0.06 & 0.24 & 32,979 & 0.15 & 0.36 & 34,230 & 0.15 & 0.35 & 4,281 & 1.00 & 0.00 \\
\hline Number of Children & 29,962 & 0.85 & 1.31 & 31,194 & 0.85 & 1.31 & 32,559 & 0.86 & 1.32 & 33,791 & 0.86 & 1.32 & 4,230 & 1.09 & 1.52 \\
\hline Less than HS & 30,357 & 0.53 & 0.50 & 31,608 & 0.53 & 0.50 & 32,979 & 0.54 & 0.50 & 34,230 & 0.54 & 0.50 & 4,281 & 0.66 & 0.47 \\
\hline HS & 30,357 & 0.47 & 0.50 & 31,608 & 0.47 & 0.50 & 32,979 & 0.46 & 0.50 & 34,230 & 0.46 & 0.50 & 4,281 & 0.34 & 0.47 \\
\hline Before 1950 & 30,357 & 0.00 & 0.00 & 31,608 & 0.00 & 0.00 & 32,979 & 0.00 & 0.00 & 34,230 & 0.00 & 0.00 & 4,281 & 0.00 & 0.00 \\
\hline 1950-1959 & 30,357 & 0.00 & 0.02 & 31,608 & 0.00 & 0.03 & 32,979 & 0.00 & 0.03 & 34,230 & 0.00 & 0.04 & 4,281 & 0.00 & 0.06 \\
\hline 1960-1964 & 30,357 & 0.00 & 0.04 & 31,608 & 0.00 & 0.04 & 32,979 & 0.00 & 0.04 & 34,230 & 0.00 & 0.04 & 4,281 & 0.01 & 0.08 \\
\hline 1965-1969 & 30,357 & 0.00 & 0.05 & 31,608 & 0.00 & 0.05 & 32,979 & 0.00 & 0.06 & 34,230 & 0.00 & 0.06 & 4,281 & 0.02 & 0.12 \\
\hline $1970-1974$ & 30,357 & 0.00 & 0.06 & 31,608 & 0.01 & 0.07 & 32,979 & 0.00 & 0.07 & 34,230 & 0.01 & 0.08 & 4,281 & 0.02 & 0.15 \\
\hline $1975-1979$ & 30,357 & 0.01 & 0.09 & 31,608 & 0.01 & 0.11 & 32,979 & 0.01 & 0.10 & 34,230 & 0.01 & 0.11 & 4,281 & 0.05 & 0.22 \\
\hline 1980-1985 & 30,357 & 0.02 & 0.13 & 31,608 & 0.02 & 0.15 & 32,979 & 0.02 & 0.13 & 34,230 & 0.02 & 0.15 & 4,281 & 0.10 & 0.30 \\
\hline 1986-1989 & 30,357 & 0.01 & 0.11 & 31,608 & 0.02 & 0.14 & 32,979 & 0.01 & 0.11 & 34,230 & 0.02 & 0.13 & 4,281 & 0.08 & 0.27 \\
\hline $1990-1993$ & 30,357 & 0.02 & 0.13 & 31,608 & 0.03 & 0.16 & 32,979 & 0.02 & 0.13 & 34,230 & 0.02 & 0.15 & 4,281 & 0.10 & 0.30 \\
\hline 1994-1999 & 30,357 & 0.01 & 0.10 & 31,608 & 0.02 & 0.13 & 32,979 & 0.01 & 0.10 & 34,230 & 0.02 & 0.13 & 4,281 & 0.07 & 0.25 \\
\hline State Unemployment Rate & 30,357 & 5.04 & 1.32 & 31,608 & 5.06 & 1.33 & 32,979 & 5.09 & 1.34 & 34,230 & 5.11 & 1.35 & 4,281 & 5.72 & 1.49 \\
\hline
\end{tabular}

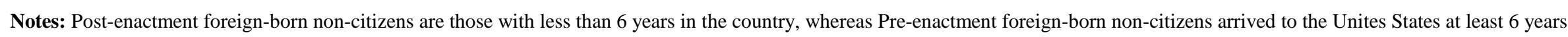
ago. 